\title{
Application of German Climate Change Adaptation Strategy for Federal State of Saxony-Anhalt, Germany.
}

\author{
Eklavyya Popat ${ }^{1}$, Falk Böttcher ${ }^{2}$
}

\begin{abstract}
Implementation of the German Climate change Strategy in the Federal State of Saxony-Anhalt is discussed in this paper. It shares the requirement and importance of sustainable development. An overview of strategy, The DAS Indicator System is provided with results of a portion of work being done for the ministry of agriculture by Deutscher Wetterdienst (DWD). Applicability of the indicator system is also shown by evaluation of results for specific indicators from 1961-2015.
\end{abstract}

Index Terms - Climate Change, Climatic Water Balance, Irrigation, Natural Snow Cover, The DAS Indicator Project, Saxony-Anhalt, Soil Moisture Content.

\section{INTRODUCTION}

$\mathrm{I}_{\mathrm{a}}^{\mathrm{n}}$ December 2008, the Federal Government Of Germany approved the Adaptation strategy to Climate Change (DAS). It describes the areas in which Climate change is already being observed, along with basic possibilities for action and requirements in different sectors. There are 13 fields of action in which DAS is addressed are: Human health; Pre-construction areas; Water resources, Water management, Coastal and Coastal areas Sea protection; Soil; Biological Diversity; Agriculture; Forestry; Fishing; Energy Sciences; Financial management; Transport, Transport infrastructure; Industry and Commerce as well as Tourism. The strategy is in consideration with the city, regional and urban planning as well as human population conservation. Hence, it is applicable in several areas [1].

The DAS sets a strategic framework for the climate change and the impulses of action in all social sectors. Changes due to climate change must be applied systematically to all relevant planning processes and development strategies. The goal is to make the natural and social systems adaptable for climate change in future. Most Federal states have given the national strategy the impetus, to adapt to country-specific adaptation strategies or adaptation aspects in their climate protection strategies to be recorded.

In order to further develop, the Federal Government has a cross-departmental body for discussion and coordination of the

"This work is affiliated to Agro-Meteorological department of Deutscher Wetterdienst, Kärrnerstraße 68,04288 Leipzig, Germany”.

${ }^{1}$ Eklavyya Popat, Masters Student at Faculty of Environmental Sciences, Technische Universität Dresden, 01062 Dresden, Germany (email: eklavyya.popat@mailbox.tu-dresden.de, eklavyya.popat@gmail.com ). process. Inaugurated in August 2011, on the adaption of the "Action plans Adaptation of the German Adaptation Strategy on climate change "(APA). The APA has underlined the objectives and options for action described in the DAS with required specific activities and links. The DAS with other national strategy particularly stresses on the responsibility of the Confederation for the provision of knowledge and information, for consideration of adaptation requirements.

\section{THE DAS INDICATOR SYSTEM}

The indicators included in the system were used for more than five years by development and reconciliation process representatives from different ministries in federal states and also partly at country level as well as with non-governmental experts.

With reference to the 13 fields of action and two cross sections of the DAS on the impacts due to climate change and on already initiated adaptation processes.

Overall DAS indicator system comprises 97 Indicators, 55 of which describe effects due to climate change (impact indicators), 42 describe adaptive measures or activities and conditions that support the customization process (Response indicators). In addition, there are five across the board, which provide overlapping activities of the Federal Government, with which the adaptation process to climate change is supported ${ }^{[1]}$. Due to limited data availability, it is not possible to have all relevant discussions, processes and action approaches with the indicators. A lot is withdrawn from the quantitative analysis and illustration. Many data collections are also available only at the beginning and it takes longer time series for Interpretation of developments. Restrictions on data availability also have the consequence that the current number of indicators per field of action or cross-section is not necessarily the case of importance. Hence accordingly, the indicator system has been further developed. For many indicators, make specific contribution for climate change, environment, society and economy.

The Indicator system comprises 102 indicators, the monitoring report runs for 256 pages (approx.) ${ }^{[2]}$. The documentation system supports the indicator the process of updating

${ }^{2}$ Falk Böttcher, Head of Department of Agro-Meteorology, Deutscher Wetterdienst (DWD), Kärrnerstraße 68, 04288 Leipzig, Germany (e-mail: Falk.Boettcher@dwd.de ). 
documentation; the data sources and the reporting process. This documentation system is designed to ensure the complete repeatability of calculations.

\section{STUDY AREA - SAXONY-ANHALT}

Saxony-Anhalt is one of the sixteen Federal states of Germany. It shares borders with states of Brandenburg to the east, Saxony to the south, Thuringia to the southwest, and Lower Saxony to the northwest. The state capital is Magdeburg and has an Area of 7,895 square miles $(20,447 \text { square } \mathrm{km})^{[2]}$.

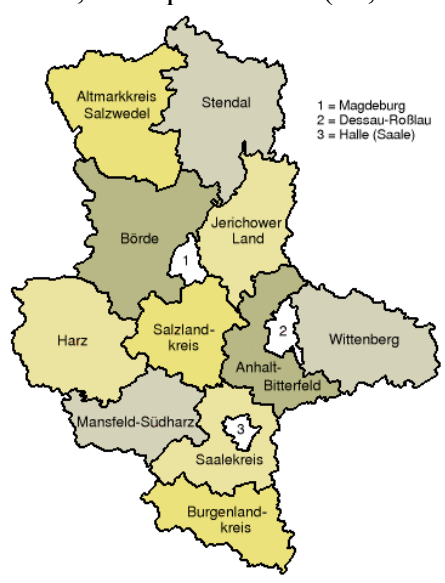

Fig 1: State of Saxony-Anhalt ${ }^{[4]}$

Geography - In the north, the Saxony-Anhalt landscape is normally plain (North German Plain). The old Hanseatic towns Salzwedel, Gardelegen, Stendal, and Tangermünde are located in the Altmark. The Colbitz-Letzlingen Heath and the Drömling near Wolfsburg marks the transition between the Altmark region and the Elbe-Börde-Heath region. Some notable towns in the Magdeburg Börde are Haldensleben, Oschersleben (Bode), Wanzleben, Schönebeck (Elbe), Aschersleben and the capital Magdeburg. The Harz Mountains are located in the south-west, comprising the Harz National Park, the Harz Foreland and Mansfeld Land. The highest mountain of the Harz (and of Northern Germany) is Brocken, with an elevation of 1,141 meters $(3,735 \mathrm{ft})$. In this area, are the towns Halberstadt, Wernigerode, Thale, Eisleben and Quedlinburg. The fertile lowlands of the Börde region and of the Saale and Mulde river valleys support the cultivation of wheat, rye, barley, rape, sugar beets, and fodder crops ${ }^{[2]}$.

\section{INDICATORS FOR SAXONY-ANHALT}

There are 34 Indicators which for the Federal state of Saxony Anhalt. The data on indicators are taken from several stations with in the stated located at different topographical locations. Various organizations work on these indicator-data to understand and reports on requirement of adaptations for the respective fields.

The Indicators listed for Saxony Anhalt are Ground water
Quantity (Mengenmäßiger Grundwasserzustand); Ground Water Recharge(Grundwasserneubildung); Average Runoff(Mittlerer Abfluss); Water Drainage(Hochwasserabfluss); Low Water (Niedrigwasser); Water Temperature(Wassertemperatur stehender Gewässer); Soil Moisture Content (Bodenwasservorrat); Soil Temperature (Bodentempratur); Beginning and End of Frost-Free Days (Beginn und Ende Frostfreiheit); Flowering of Apple (Blühbeginn Apfel); Permanent Phenological Vegetation Period (Dauer phänologische Vegetationsperiode); Developed Humus Content (Entwicklung Humusgehalt); Plant diseases (Schaderregerbefall); Quality of Crop Poducts (Quälität von Ernteprodukten); Climatic Water Balance (Klimatische Wasserbilanz); Air Temperature (Lufttemperature); Precipitation (Niederschlag); Need for Irrigation (Beregnungsbedürftigekeit); Growth of Indigenous and Imported tree species (Wunchsverhalten einheimischer und eingerführter Baumarten); Tree Species Composition in Natural Forest (Baumartenzusammensetzung in Naturwaldreservaten); Wild Forest Fire (Waldbradgefährdung); State of Forest (Waldzustand); Development cycles of forestry relevant insects (Entwicklungszyklen von forstwirtschaftlich relevanten insecten); Development humus in forest soil layers (Entwicklung Humusvorrat in forest boden); Area changes of climate-sensitive species (Arealveränderungen klimasensitiver Arten); Phenological changes in wild plants (Phänologische Veränderungen bei Wildpflanzen); Thermal stress in cities (Wärmebelastung in Städten); Summer heat effect (Sommerlicher Wärmeinseleffekt); Special energy consumption private households for space heat (Spez. Energieverbrauch priv. Haushalte für Raumwärme); Navigability of Inland waterways (Schiffbarkeit der Binnen Schiffahrtsstraßen); Diversification of Electricitiy Production (Diversifizierung der Elektrizitätserzeugung); Natural Snow Cover for regions above 500m (Natürliche scheedecke im Harz ab $500 \mathrm{~m}$ Höhenlage).

This paper discusses a small portion of work being done on DAS Indicator System for Saxony-Anhalt in AgroMeteorological department of DWD, Leipzig. The indicators taken into account are Soil Moisture Content (Bodenwasserverrat), Climate Water Balance (KWB), Irrigation (Beregrung), and Natural Snow Cover (Natürliche Schneebedeckung). The stations for data collection are located in Lowlands (Tiefland), Black Soil Area (Schwarzdegebiet), Eastern Saxony-Anhalt (Östland Sachsen-Anhalt) and Mountainous region (Harz); namely Bernburg, Gardernlegen, Wittenberg and Harzgerode respectively. Brocken and Schierke are stations used for indicator Natural Snow Cover.

The Indicators where measured for specific crop types Maize (Mais), Grass (Gras), Summer Barley (Sommergerste), Winter Rapeseed (Winterraps), Winter Wheat (winterweizen), and Sugar Beet (Zuckerrübe).

Software used are MEVER (Modelling) and Microsoft Excel (Statistical Analysis). 
IV. Software And Methodology

Software:

METVER is a complex 1D-water budget model for the calculation of the water budget of agricultural production areas with a withdrawal and a supplementary sector. The necessary model input is divided into three groups a) Meteorological data, b) Plant-related data and c) Soil-related data.

Microsoft Excel is a basic spreadsheet using a grid of cells arranged in numbered rows and letter-named columns to organize data manipulations with features of calculation, graphical tools and pivot tools ${ }^{[3]}$.

\section{Methodology}

As per guidelines in "Monitoringbericht zur Deutschen Anpassungsstrategie an den Klimawandel(2015)" data from the mentioned four stations are collected from 1961 to 2015 for the mentioned indicators. Each indicator is analyzed separately and in case of missing data interpolation is done with simple regression evaluation procedure.

\section{Evaluation of Results}

The results are evaluated in two parts a) for a 30years period of 1961-1990; and b) for a 25 years period of 1991-2015.

a. Soil Moisture Content (Bodenwasserverrat)-

\begin{tabular}{|c|c|c|c|c|c|c|c|c|c|c|c|c|}
\hline Region & \multicolumn{6}{|c|}{ 1966-1990 } & \multicolumn{6}{|c|}{$1999-2015$} \\
\hline & Gras & Mais & mmergerste & \begin{tabular}{|l|l} 
Winterraps \\
\end{tabular} & Winterweizen & Zuckerribes & Gras & Mais & Sommergẹ & Winterraps & Winterweit & Zuckerrübe \\
\hline Schwarrdegebiet & 204 & 205 & 205 & 203 & 202 & 205 & 208 & 210 & 210 & 207 & 207 & 146 \\
\hline Tiefland & 68 & 173 & 173 & 172 & 172 & 173 & 68 & 166 & 166 & 166 & 165 & 166 \\
\hline |stland Sachlser-Anhalt & 132 & 68 & 68 & 67 & 67 & 68 & 129 & 70 & 70 & 69 & 69 & 70 \\
\hline Harz & & 227 & 227 & 226 & 226 & 227 & 222 & 223 & 223 & 222 & 222 & 223 \\
\hline
\end{tabular}



Fig 2: Evaluation results for Soil Moisture Content.

b. Climate Water Balance (KWB)-

\begin{tabular}{|c|c|c|c|c|c|c|} 
Region & \multicolumn{3}{|c|}{$1961-1990$} & \multicolumn{3}{c|}{$1991-2015$} \\
\hline & Jahr & Sommer & Winter & Jahr & Sommer & Winter \\
\hline Schwarzdegebiet & $-69,9$ & $-142,8$ & 72,0 & $-123,7$ & $-201,1$ & 77,2 \\
\hline Tiefland & $-48,5$ & $-181,4$ & 129,9 & $-97,3$ & $-223,5$ & 126,4 \\
\hline Östland Sachsen-Anhalt & $-83,9$ & $-215,2$ & 129,5 & $-91,2$ & $-225,6$ & 134,1 \\
\hline Harz & 50,7 & $-126,7$ & 175,2 & $-9,8$ & $-167,1$ & 155,9 \\
\hline
\end{tabular}
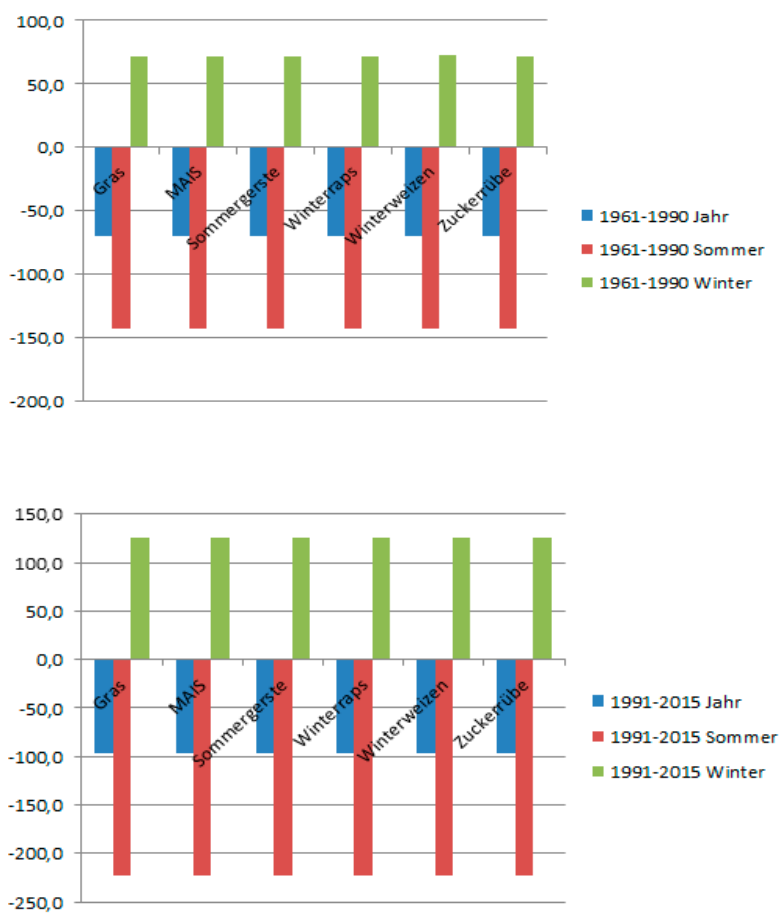

Fig 3\&4: Evaluation results for Climatic Water Balance.

c. Irrigation (Beregrung)-

\begin{tabular}{|c|c|c|c|c|c|c|c|c|c|c|c|c|c|c|c|c|c|c|c|c|c|c|c|}
\hline \multirow[t]{3}{*}{ Region } & \multicolumn{11}{|c|}{$1961-1990$} & \multicolumn{12}{|c|}{ 1961-1990 } \\
\hline & $\mathrm{Gr}$ & ras & Mais & Somme & rgerste & Winter & rapps & Winten & nveizen & Zucker & & $G$ & & Ma & & Sommer & rgerste & Winter & & Winten & veien! & Zucken & \\
\hline & VP1 & & VP1 VP2 & VP1 & VP2 & VP1 & VP2 & \begin{tabular}{l|l} 
VP1 \\
\end{tabular} & VP2 & VP1 & VP2 & vp1 & VP2 & VP1 & VP2 & VP1 & VP2 & VP1 & VP2 & VP1 & VP2 & VP1 & VP2 \\
\hline So & 13 & 23 & 1018 & 10 & 16 & 16 & 29 & 16 & 31 & 10 & 20 & 11 & 29 & 7 & 22 & 7 & 17 & 16 & 36 & 13 & 38 & 7 & 23 \\
\hline Ifetilan & 43 & 38 & $14 \quad 23$ & 13 & 21 & 21 | 21 & 36 & 21 & 37 & 14 & 24 & 53 & 45 & 14 & 33 & 14 & 29 & 25 & 46 & 25 & 47 & 14 & 35 \\
\hline Ind Sachsen-Anhalt & 26 & \begin{tabular}{|l|l|l|}
42 & 4 \\
\end{tabular} & $40 \quad 44$ & 39 & 41 & 50 & 52 & 50 & 53 & 40 & 45 & 25 & 40 & 43 & 41 & 43 & 39 & 58 & 48 & 58 & 49 & 43 & 42 \\
\hline Harz & 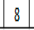 & 20 & 716 & 7 & 14 & 11 & 26 & 11 & 27 & 7 & 17 & 7 & 27 & 3 & 20 & 3 & 15 & 9 & 34 & 9 & 35 & 4 & 22 \\
\hline
\end{tabular}


Fig 5\& 6: Evaluation results for Irrigation. 


\section{d. Natural Snow Cover (Natürliche Schneebedeckung)-}

\begin{tabular}{|l|c|c|}
\hline Region & $1961-1990$ & $1991-2015$ \\
\hline Brocken & 166 & 145 \\
\hline Schierke & 112 & 84 \\
\hline
\end{tabular}

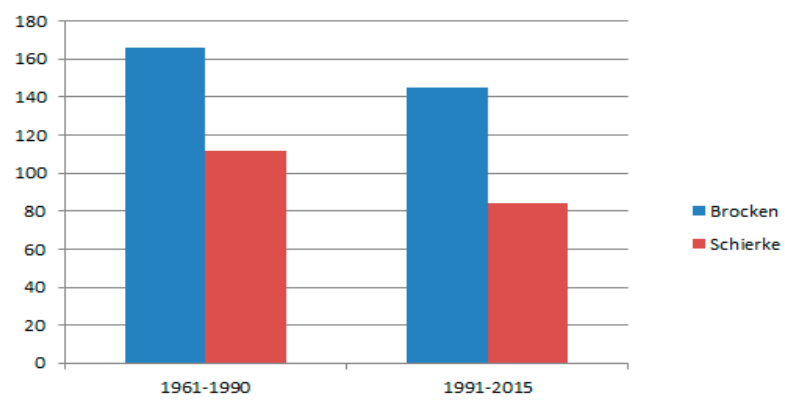

Fig 7: Evaluation results for Natural Snow Cover

\section{CONCLUSION}

The assessment of the DAS indicators relates to statistical trend calculation and assessment.

Trend description:

$\begin{aligned} \text { i. } & \text { Rising trend } \\ \text { ii. } & \text { Falling trend } \\ \text { iii. } & \text { Trend with trend reversal: } \\ \text { iv. } & \text { First falling, then rising } \\ \text { v. } & \text { Trend with trend reversal: } \\ \text { vi. } & \text { First rising, then falling }\end{aligned}$

Trend Assessment:

$\begin{aligned} \text { i. } & \text { Cheap development } \\ \text { ii. } & \text { Unfavorable development } \\ \text { iii. } & \text { No evaluation of the development } \\ \text { iv. } & \text { possible }\end{aligned}$

The trend is in the right direction when the evaluation always takes place with a view to the meso-complex climate change and adaptation.

However, the assessment of trends does not appear in all cases useful as the consequences of the changes are not always known. Thus, the description of the consequence is limited to the result of the trend calculation.

Within the framework of the statistical trend calculation, the time series with regard to their trend histories. Both rising and falling are distinguished trends as well as trends with a trend reversal.

Taking into account trends with trend reversals especially when looking at longer time series also describes developmental processes in which negative trends also plays a role in on-going adjustment measures for recent times.
Trends are used for all-time series with seven and more data points. In the trend calculation, all the data points of the available time series are included. Data series that have too few data points or irregular and temporal distant surveys are carried out by of the trend calculation

\section{REFERENCES}

[1] Konstanze Schönthaler, Stefan von Andrian-Werburg, Petra van Rüth, Susanne Hempen (May, 2015). Monitoringbericht zur Deutschen Anpassungsstrategie an den Klimawandel; pg 7.

[2] William H. Berentsen (2015). Contemporary Europe: A Geographical Analysis.

[3] Konstanze Schönthaler, Stefan von Andrian-Werburg (September, 2015). Evaluation of the German Strategy for Adaption to Climate Change (DAS) - Reporting and Closing Indicator Gaps; pg. 92.

[4] http://www.stala.sachsen-anhalt.de/gk/fms/fms111.htm

[5] Harvey, Greg (2006). Excel 2007 For Dummies. Wiley. ISBN 0-47003737-7.

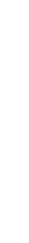

